\title{
Front Matter: Volume 9998
}

, "Front Matter: Volume 9998," Proc. SPIE 9998, Remote Sensing for Agriculture, Ecosystems, and Hydrology XVIII, 999801 (19 December 2016); doi: $10.1117 / 12.2263840$

SPIE. Event: SPIE Remote Sensing, 2016, Edinburgh, United Kingdom 


\title{
Remote Sensing for Agriculture, Ecosystems, and Hydrology XVIII
}

\author{
Christopher M. U. Neale \\ Antonino Maltese \\ Editors
}

\section{6-28 September 2016 \\ Edinburgh, United Kingdom}

Sponsored by

SPIE

Cooperating Organisations

Innovation Centre for Sensor and Imaging Systems (United Kingdom)

ADS Scotland (United Kingdom)

The Knowledge Transfer Network (United Kingdom)

Visit Scotland (United Kingdom)

European Regional Development Fund (Belgium)

Technology Scotland (United Kingdom)

European Association of Remote Sensing Companies (Belgium)

European Association of Remote Sensing Laboratories (Germany)

The British Association of Remote Sensing Companies (United Kingdom)

Remote Sensing \& Photogrammetry Society (United Kingdom)

Published by

SPIE

Volume 9998 
The papers in this volume were part of the technical conference cited on the cover and title page. Papers were selected and subject to review by the editors and conference program committee. Some conference presentations may not be available for publication. Additional papers and presentation recordings may be available online in the SPIE Digital Library at SPIEDigitallibrary.org.

The papers reflect the work and thoughts of the authors and are published herein as submitted. The publisher is not responsible for the validity of the information or for any outcomes resulting from reliance thereon.

Please use the following format to cite material from these proceedings:

Author(s), "Title of Paper," in Remote Sensing for Agriculture, Ecosystems, and Hydrology XVIII, edited by Christopher M. U. Neale, Antonino Maltese, Proceedings of SPIE Vol. 9998 (SPIE, Bellingham, WA, 2016) Six-digit Article CID Number.

ISSN: 0277-786X

ISSN: 1996-756X (electronic)

ISBN: 9781510604001

ISBN: 9781510604018 (electronic)

Published by

SPIE

P.O. Box 10, Bellingham, Washington 98227-0010 USA

Telephone +1 3606763290 (Pacific Time) · Fax +1 3606471445

SPIE.org

Copyright @ 2016, Society of Photo-Optical Instrumentation Engineers.

Copying of material in this book for internal or personal use, or for the internal or personal use of specific clients, beyond the fair use provisions granted by the U.S. Copyright Law is authorized by SPIE subject to payment of copying fees. The Transactional Reporting Service base fee for this volume is $\$ 18.00$ per article (or portion thereof), which should be paid directly to the Copyright Clearance Center (CCC), 222 Rosewood Drive, Danvers, MA 01923. Payment may also be made electronically through CCC Online at copyright.com. Other copying for republication, resale, advertising or promotion, or any form of systematic or multiple reproduction of any material in this book is prohibited except with permission in writing from the publisher. The CCC fee code is 0277-786X/16/\$18.00.

Printed in the United States of America.

Publication of record for individual papers is online in the SPIE Digital Library.

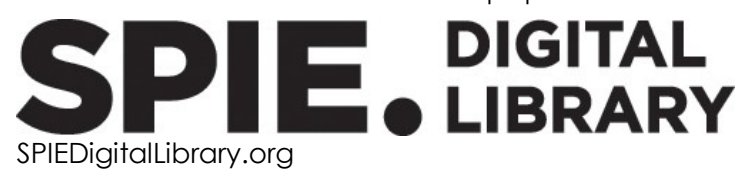

Paper Numbering: Proceedings of SPIE follow an e-First publication model. A unique citation identifier (CID) number is assigned to each article at the time of publication. Utilization of CIDs allows articles to be fully citable as soon as they are published online, and connects the same identifier to all online and print versions of the publication. SPIE uses a six-digit CID article numbering system structured as follows:

- The first four digits correspond to the SPIE volume number.

- The last two digits indicate publication order within the volume using a Base 36 numbering system employing both numerals and letters. These two-number sets start with 00, 01, 02, 03, 04, 05, $06,07,08,09,0 A, 0 B \ldots$. OZ, followed by 10-1Z, 20-2Z, etc. The CID Number appears on each page of the manuscript. 


\title{
Contents
}

\author{
ix Authors \\ xi Conference Committee \\ xiii Introduction
}

\section{SESSION 1 RADAR AND LIDAR APPLICATIONS IN AGRICULTURE}

999802 Using RADARSAT-2 and TerraSAR-X satellite data for the identification of canola crop phenology [9998-1]

999803 Satellite-based monitoring of grassland: assessment of harvest dates and frequency using SAR [9998-2]

999804 Integration of manual channel initiation and flow path tracing in extracting stream features from lidar-derived DTM [9998-58]

999805 Analysis of SAR and optical temporal signatures of grapevine over a heterogeneous vineyard landscape [9998-4]

\section{SESSION 2 PRECIPITATION, RUNOFF AND FLOODING}

999806 Glacier stagnant in central Karakorum during 2003 to 2008 derived from DEOS Mass Transport Model GRACE data and one monthly degree-day model [9998-6]

999807 Land cover/use scenario building and its impact on runoff process inside the lligan river basin [9998-7]

999808 An assessment of the Height Above Nearest Drainage terrain descriptor for the thematic enhancement of automatic SAR-based flood monitoring services [9998-8]

999809 GIS-based flood risk model evaluated by Fuzzy Analytic Hierarchy Process (FAHP) [9998-9]

\section{SESSION $3 \quad$ AGRICULTURAL MONITORING}

9998 0A Options for using Landsat and RapidEye satellite images aiming the water productivity assessments in mixed agro-ecosystems [9998-11]

SESSION 4 SPECIAL SESSION HONORING DR. MANFRED OWE: REMOTE SENSING OF SOIL MOISTURE

9998 OF Soil water content assessment: seasonal effects on the triangle method [9998-17] 
$9998 \mathrm{OH} \quad$ Sixteen years of agricultural drought assessment of the BioBío region in Chile using a $250 \mathrm{~m}$ resolution Vegetation Condition Index ( $\mathrm{VCl}$ ) (Runner-Up Best Student Paper Award) [9998-19]

$9998 \mathrm{Ol}$ Comparison of different spatial sampling methods for validation of GEOV1 FVC product over heterogeneous and homogeneous surfaces [9998-20]

9998 0J Dynamics modeling for sugar cane sucrose estimation using time series satellite imagery [9998-62]

9998 OK Aerial image mosaics built using images with vegetation index pre-calculated [9998-22]

9998 OL Mapping Prosopis spp. within the Tarach water basin, Turkana, Kenya using Sentinel-2 imagery [9998-23]

\section{SESSION 6 ENERGY BALANCE AND EVAPOTRANSPIRATION}

9998 OM Energy balances in sugar cane, coffee and natural vegetation in the northeastern side of the São Paulo state, Brazil [9998-24]

$99980 \mathrm{~N}$ Continuous evapotranspiration monitoring and water stress at watershed scale in a Mediterranean oak savanna [9998-25]

999800 Energy balance in the watershed of Ipê, Northwestern São Paulo State, Brazil [9998-26]

9998 OP Modelling evapotranspiration using the modified Penman-Monteith equation and MODIS data over the Albany Thicket in South Africa [9998-51]

9998 OR Discrepancies between eddy covariance and lysimeter measurements in the assessment of energy balance modeling in vineyards [9998-29]

9998 OS Measuring evapotranspiration using an eddy covariance system over the Albany Thicket of the Eastern Cape, South Africa [9998-30]

\section{SESSION 7 HYDROLOGY}

9998 OT Validation points generation for LiDAR-extracted hydrologic features [9998-32]

9998 OU Water resource monitoring in semi-arid environment through the synergic use of SAR data and hydrological models [9998-33]

9998 OV Impact of dynamically changing land cover on runoff process: the case of lligan river basin [9998-56] 
9998 OW A synergistic approach using optical and SAR data to estimate crop's irrigation requirements [9998-35]

9998 OX Irrigation network extraction methodology from LiDAR DTM using Whitebox and ArcGIS [9998-36]

9998 OY Remote sensing for developing world agriculture: opportunities and areas for technical development (Best Student Paper Award) [9998-37]

\section{SESSION 9 SPECTRORADIOMETRY AND HYPERSPECTRAL APPLICATIONS}

999810 Assessing the ratio of leaf carbon to nitrogen in winter wheat and spring barley based on hyperspectral data [9998-39]

$999811 \quad$ High-resolution sensing for precision agriculture: from Earth-observing satellites to unmanned aerial vehicles [9998-74]

999812 Detection of chlorophyll and leaf area index dynamics from sub-weekly hyperspectral imagery [9998-41]

999813 Detecting subtle environmental change: a multi-temporal airborne imaging spectroscopy approach [9998-42]

999814 Evaluating the potential of image fusion of multispectral and radar remote sensing data for the assessment of water body structure [9998-49]

999815 The estimation the Great Lakes net basin supply: implications for water level fluctuations [9998-45]

999816 Monitoring of artificial water reservoirs in the Southern Brazilian Amazon with remote sensing data [9998-71]

999817 Operational monitoring of turbidity in rivers: how satellites can contribute [9998-48]

999818 Determination of bank structures and river width variations using remote sensing data [9998-44]

\section{POSTER SESSION}

9998 1B Reproducibility of crop surface maps extracted from Unmanned Aerial Vehicle (UAV) derived digital surface maps [9998-5] 
9998 1C Energy balance model applied to pasture experimental areas in São Paulo State, Brazil [9998-50]

9998 1D Evapotranspiration, biomass production and water productivity acquired from Landsat 8 images in the northwestern side of the São Paulo state, Brazil [9998-52]

$99981 \mathrm{E} \quad$ Annual variability of water productivity components in the watershed of Cabeceira Comprida stream, Santa Fé do Sul, Brazil [9998-53]

$99981 \mathrm{G} \quad$ Mapping paddy biomass with multiple vegetation indexes by using multispectral remotely sensed image [9998-60]

$99981 \mathrm{H} \quad$ Water productivity mapping using Landsat 8 satellite together with weather stations [9998-61]

$99981 \mathrm{~J} \quad$ Rice identification at the early stage of the rice growth season with single fine quad Radarsat-2 data [9998-64]

$99981 \mathrm{~K} \quad$ Estimating leaf nitrogen accumulation in maize based on canopy hyperspectrum data [9998-65]

$99981 \mathrm{~L}$ The role of spatial and spectral resolution on the effectiveness of satellite-based vegetation indices [9998-66]

$99981 \mathrm{M} \quad$ Mapping species distribution of Canarian Monteverde forest by field spectroradiometry and satellite imagery [9998-67]

9998 1N Biophysical indicators based on satellite images in an irrigated area at the São Francisco River Basin, Brazil [9998-68]

999810 Continuous data assimilation for downscaling large-footprint soil moisture retrievals [9998-69]

$99981 \mathrm{~A} \quad$ Application of agricultural subsidy inspection using UAV image [9998-72]

$99981 \mathrm{R} \quad$ Remote sensing in precision farming: real-time monitoring of water and fertilizer requirements of agricultural crops [9998-73]

9998 is The pan-sharpening of satellite and UAV imagery for agricultural applications [9998-76]

9998 1T Carbon sequestration associated to the land-use and land-cover changes in the forestry sector in Southern Brazil [9998-77]

$99981 \mathrm{U}$ Retrieval of leaf water content using terrestrial full-waveform lidar [9998-78]

9998 IV Forest vegetation dynamics and its response to climate changes [9998-79]

$99981 \mathrm{X} \quad$ Remote sensing-based vegetation indices for monitoring vegetation change in the semiarid region of Sudan [9998-82]

9998 1Y Regional assessment of trends in vegetation change dynamics using principal component analysis [9998-83] 
999812 Remote sensing as a tool to analyse lizards behaviour [9998-84]

999820 Snow cover detection algorithm using dynamic time warping method and reflectances of MODIS solar spectrum channels [9998-86]

999821 Satellite image based methods for fuels maps updating [9998-88]

999824 Removal of clouds, dust and shadow pixels from hyperspectral imagery using a nonseparable and stationary spatio-temporal covariance model [9998-91] 
Proc. of SPIE Vol. $9998999801-8$

Downloaded From: https://www.spiedigitallibrary.org/conference-proceedings-of-spie on 26 Apr 2023 Terms of Use: https://www.spiedigitallibrary.org/terms-of-use 


\section{Authors}

Numbers in the index correspond to the last two digits of the six-digit citation identifier (CID) article numbering system used in Proceedings of SPIE. The first four digits reflect the volume number. Base 36 numbering is employed for the last two digits and indicates the order of articles within the volume. Numbers start with 00, 01, 02, 03, 04, 05, 06, 07, 08, 09, OA, OB...0Z, followed by 10-1Z, 20-2Z, etc.

\author{
Adede, Chrisgone, $\mathrm{OL}$ \\ Adeofun, C. O., 1 Y \\ Al-Mashhawari, Samir, 1B \\ Alonso-Benito, Alfonso, 21 \\ Altaf, Muhammad U., 10 \\ Amitrano, Donato, OU \\ Anderson, M. C., ON \\ Andreu, A., ON \\ Angel, Yoseline, 12, 24 \\ Aralova, D., 1X, IY \\ Arbelo, Manuel, 1M, 21 \\ Arbelo-Bayó, Manuel, $1 \mathrm{M}$ \\ Arvor, Damien, 16 \\ Atzberger, Clement, OL \\ Baschek, Björn, 17 \\ Baup, F., 05 \\ Bayma-Silva, Gustavo, 0A, 0M, 1C, IN \\ Ben Asher, Jiftah, 1R \\ Blanken, Peter D., 15 \\ Blasco, Jennifer G., 07 \\ Bordonal, Ricardo O., $1 \mathrm{~T}$ \\ Borlongan, N. J. B., 04, OT \\ Cammalleri, C., OF \\ Capodici, F., OF \\ Carpintero, E., ON \\ Carretero, Miguel, 12 \\ Caselles, Vicente, OR \\ Catalão, João, OW \\ Choi, Sungwon, 20 \\ Chow, Candace, 08 \\ Ciraolo, G., OF \\ Coaguila, Daniel Noe, 1C, 1D, 1E, 1H \\ Cochasrk, Thomas C. D., IT \\ Corgne, S., 05 \\ Corpetti, Thomas, 16 \\ Csaplovics, E., 1X, 1Y \\ Silva, Ramon F. B., $1 T$ \\ Daher, Felipe, 16 \\ Dalezios, Nicolas R., $1 \mathrm{~L}$ \\ Darvishzadeh, Roshanak, $1 \mathrm{U}$ \\ Das, Amrita, 1Q \\ de Castro Jorge, Lúcio André, OK \\ de Castro Teixeira, Antonio Heriberto, OA, OM, \\ $00,1 \mathrm{C}, 1 \mathrm{D}, 1 \mathrm{E}, 1 \mathrm{H}, 1 \mathrm{~N}, 1 \mathrm{~T}$ \\ de Castro Victoria, Daniel, OM, IC \\ de Figueiredo, Eduardo B., $1 \mathrm{~T}$ \\ de la Cruz, R. M., 04, OT, OX \\ Dercas, Nicholas, $1 \mathrm{~L}$ \\ Di Martino, Gerardo, OU
}

Dida, Adrian I., IV

Ding, Yanling, 0 I

Doña, Carolina, OR

Dos Santos, Remi, 12

Dubreuil, Vincent, 16

Ebreo, D. J. R., OT

Feitosa, Diego G., 00

Felicen, M. M., OT

Feng, Hai-kuan, 10

Floriansitz, Matthias, OL

Franco, Renato A. M., 00, 1D, 1E, 1H

Furlan Nogueira, Sandra, 1C

Galve, Joan M., OR

Gao, F., ON

Garcia-Lazaro, Jose R., 21

Gaspa, M. C., 04

Ge, Yong, Ol

Gibson, Lesley A., OP, OS

González Dugo, M. P., ON

Gonzalez-Calvo, Alejandro, 21

Grant, K., 03

Graziano, Paulo Sergio, 0J

Gu, Xiao-he, 10, 1G, 1K

Gwate, O., OP, OS

Hain, C., ON

Han, Kyung-Soo, 20

Hart, Douglas P., OY

Hartmann, S., 03

Hernández-Leal, Pedro A., 1M, 21

Hillebrand, Gudrun, 17

Hoteit, Ibrahim, 10

Houborg, Rasmus M., 11, 12, 24

$\mathrm{Hu}$, Maogui, Ol

Hucke, Dorothee, 17

Hunger, Sebastian, 14, 18

Ignacio, Ma. Teresa T., 07, OV

Immitzer, Markus, OL

lodice, Antonio, OU

Jana, Raghavendra B., 10

Jenerowicz, Agnieszka, is

Jeunnette, Mark N., OY

Justina, Diego Della, 0J

Karrasch, Pierre, 14, 18

Kazama, Yoriko, 0J

Kereszturi, G., 13

Kopeika, Norman S., IR

Kranz, Susanne, 17

Kustas, W. P., ON

La Loggia, G., OF 
Lagos, Octavio, $\mathrm{OH}$

Lamparelli, Rubens Augusto Camargo, 0J

Lampropoulos, George, 02

Laslier, Marianne, 16

Lee, Chang suk, 20

Lee, Kyeong-sang, 20

Leivas, Janice Freitas, 0A, 0M, 1C, 1D, 1E, 1H, 1N $1 \mathrm{~T}$

Li, Yifeng, 02

Lillo-Saavedra, Mario, $\mathrm{OH}$

López-Urrea, Ramón, OR

Loussert, P., 05

Lucieer, Arko, 11

Luminari, Luigi, OL

Luppe, Maximiliam, OK

Mahor, M. A. P., OX

Maltese, A., OF

Mantel, Sukhmani K., OP, OS

Martinis, Sandro, 08

Martín-Luis, Antonio, 1M

McCabe, Matthew F., 11, 12, 1B, 10, 24

McNairn, Heather, 02

Middleton, Elizabeth M., 12

Milano, Alan E., 07, OV

Mitidieri, Francesco, OU

Montoro, Amelia, OR

Moreno-Ruiz, Jose A., 21

Moukomla, Sitthisak, 15

Navarro Ferreira, Ana, OW

Neale, Christopher M., 0O, 1E, 1H

$\mathrm{Ng}$, Wai-Tim, OL

Nieto, H., ON

Olfindo, N. T., 04, OT, OX

Ortega, A., 05

Osunmadewa, B. A., 1X, 1Y

Pacheco, Anna, 02

Palmer, Anthony R., OP, OS

Papa, Maria Nicolina, OU

Park, Jin-Ki, $1 Q$

Park, Jong-Hwa, $1 Q$

Parkes, Stephen D., 1B

Pei, Zhiyuan, $1 \mathrm{~J}$

Perez, A. M. C., 04, OT, OX

Powers, Jarrett, 02

Psomiadis, Emmanouil, $1 \mathrm{~L}$

Pullanagari, Reddy R., 13

Quénol, H., 05

R. A., Majdaldin, 1X, IY

Ribeiro da Silva Reis, João Batista, IN

Riccio, Daniele, OU

Rocha, Jansle Vieira, 0J

Rodrigues Herling, Valdo, IC

Rolim, João, OW

Ronquim, Carlos Cesar, OM, 1N, $1 \mathrm{~T}$

Rosas, Jorge, 1B

Rosendo Candido, Leandro, OK

Ruello, Giuseppe, OU

Salcedo, Stephanie Mae B., 07, 0V

Sánchez, Juan M., OR

Saraiva, Cátia, OW
Seo, Minji, 20

Seong, Noh-hun, 20

Shen, Kejian, $1 \mathrm{~J}$

Siegmund, R., 03

Sillero, Neftalí, 12

Skidmore, Andrew K., IU

Song, Xiao-yu, 10, 1G, 1K

Spyropoulos, Nikolaos V., IL

Sukcharoen, Tharapong, 09

Suson, Peter D., 07, OV

T. Hernandez, Fernando B., 0O, 1D, 1E, 1H

Teetat, Charoenkalunyuta, 09

Teodoro, Ana C., $1 \mathrm{Z}$

Twele, André, 08

Verbist, Koen, $\mathrm{OH}$

Vuolo, Francesco, OL

Wagner, M., 03

Wahome, Raphael, OL

Wang, Lizhi, 1K

Wang, Tiejun, $1 \mathrm{U}$

Wang, Yancang, $1 \mathrm{G}$

Weng, Jingnong, 09

Wessollek, Christine, 14

Winterscheid, Axel, 17

Woroszkiewicz, Malgorzata, is

$\mathrm{Xu}, \mathrm{BO}, 10$

$X u$, Junli, 06

$X U$, Xin-gang, 10, 1G, $1 \mathrm{~K}$

Yang, Gui-jun, 10

Yu, Hai-yang, 10

Yule, Ian J., 13

Zambrano, Francisco, $\mathrm{OH}$

Zhang, Hongyan, Ol

Zhang, Pengbin, $1 \mathrm{~J}$

Zhang, Shiqiang, 06

Zhang, Xiaoqian, $1 \mathrm{~J}$

Zhang, Xiaowen, 06

Zhao, Yu, OJ

Zhu, Xi, IU

Zilberman, Arkadi, $1 \mathrm{R}$

Zoran, Liviu Florin V., IV

Zoran, Maria A., IV 


\section{Conference Committee}

Symposium Chair

Klaus Schäfer, (Retired) Karlsruhe Institute of Technology, Institute of Meteorology and Climate Research (Germany)

Symposium Co-chairs

Christopher M. U. Neale, University of Nebraska-Lincoln (United States) Daugherty Water for Food Institute (United States)

Iain H. Woodhouse, The University of Edinburgh (United Kingdom), Geography and the Lived Environment Research Institute (United Kingdom)

\section{Conference Chairs}

Christopher M. U. Neale, University of Nebraska-Lincoln (United States) Daugherty Water for Food Institute (United States)

Antonino Maltese, Università degli Studi di Palermo (Italy)

Conference Programme Committee

Wim G. M. Bastiaanssen, UNESCO (France)

Antonino Maltese, Università degli Studi di Palermo (Italy)

Christopher M. U. Neale, University of Nebraska-Lincoln (United States)

Daugherty Water for Food Institute (United States)

\section{Session Chairs}

1 Radar and Lidar Applications in Agriculture

Antonino Maltese, Università degli Studi di Palermo (Italy)

2 Precipitation, Runoff and Flooding

Antonino Maltese, Università degli Studi di Palermo (Italy)

3 Agricultural Monitoring

Wim G. M. Bastiaanssen, UNESCO (France)

4 Special Session Honoring Dr. Manfred Owe: Remote Sensing of Soil Moisture

Christopher M. U. Neale, University of Nebraska-Lincoln (United States)

Daugherty Water for Food Institute (United States) 
5 Vegetation Patterns and Dynamics

Christopher M. U. Neale, University of Nebraska-Lincoln (United States)

Daugherty Water for Food Institute (United States)

6 Energy Balance and Evapotranspiration

Antonino Maltese, Università degli Studi di Palermo (Italy)

7 Hydrology

Wim G. M. Bastiaanssen, UNESCO (France)

8 Irrigation Water Management

Christopher M. U. Neale, University of Nebraska-Lincoln (United States) Daugherty Water for Food Institute (United States)

9 Spectroradiometry and Hyperspectral Applications

Antonino Maltese, Università degli Studi di Palermo (Italy)

10 Rivers and Lakes

Christopher M. U. Neale, University of Nebraska-Lincoln (United States)

Daugherty Water for Food Institute (United States) 


\section{Introduction}

This proceedings volume contains papers presented during the conference on Remote Sensing for Agriculture, Ecosystems, and Hydrology. The conference was part of the international symposium on Remote Sensing sponsored by SPIE - The International Society for Optics and Photonics. The symposium was held at the Edinburgh International Conference Centre, Edinburgh, United Kingdom, from the 26th to 29th of September 2016.

The 2016 conference was dedicated to honoring Manfred Owe, former chair of the Remote Sensing for Agriculture, Ecosystems, and Hydrology Conference of SPIE Remote Sensing. He passed away earlier this year in Baltimore, Maryland. Through his decade-long involvement from 2000 to 2009, Manfred made considerable contributions to the success of the event.

39 oral and 24 poster papers were presented during this year's conference, covering a broad range of topics in the field of remote sensing applications in environmental science.

The program was organized into 10 sessions according to major themes such as: Radar and Lidar Applications in Agriculture; Agricultural Monitoring; Irrigation Water Management; Spectroradiometry and Hyperspectral Applications; Vegetation Patterns and Dynamics; Hydrology; Precipitation Runoff and Flooding; Energy Balance and Evapotranspiration; and Rivers and Lakes.

A special session on Remote Sensing of Soil Moisture was dedicated in Manfred Owe's memory. Manfred was a senior scientist emeritus at NASA Goddard Space Flight Center (United States) and a dear colleague.

We extend our gratitude to Dr. Richard A.M. de Jeu the Managing Director at VanderSat (Netherlands) and close collaborator of Manfred Owe, for giving an invited presentation entitled "Deriving reliable soil moisture using passive microwave satellite instruments: a tribute to Dr. Manfred Owe" [9998-15]. We also thank Dr. Wim G. M. Bastiaanssen of UNESCO-IHE Institute for Water Education (Netherlands) - who also served as a program committee member and chaired two sessions - for giving an invited presentation on "Pixel-based surface runoff based on soil moisture variability as an input for global surface water accounting" [9998-16]. Dr. Bastiaanssen also gave a keynote address during the opening plenary session on Earth Observations for Improving Water and Food Security.

The poster sessions also had good representation from the above-mentioned themes. The presentations described both fundamental and applications-based research activities including modeling, laboratory and field experiments, and operational applications. 
An SPIE Best Paper Presentation Award was designed to encourage and acknowledge excellence in student paper presentation. The 2016 conference award has been assigned to Mark N. Jeunnette from Massachusetts Institute of Technology (United States) for giving a presentation on a parameterized numerical model implemented to compare platform options for collecting aerial imagery to support agriculture electronic information services in developing countries. The corresponding awarded paper is entitled "Remote sensing for developing world agriculture: opportunities and areas for technical development" [9998-37].

Our appreciation and gratitude goes also to the presenters for their efforts and to the participants for their insightful questions and discussions. Special thanks are also due to the host city for the excellent venue, and to: Alexandra Pluchart Rusova (conference program coordinator), Margaret Grasseschi (conference proceedings coordinator), Karin Burger (Manager at SPIE Europe), and all the SPIE organizational staff for their support prior to, during, and after the symposium. We look forward to an even more successful conference in 2017 in Warsaw, Poland.

Christopher M. U. Neale Antonino Maltese 